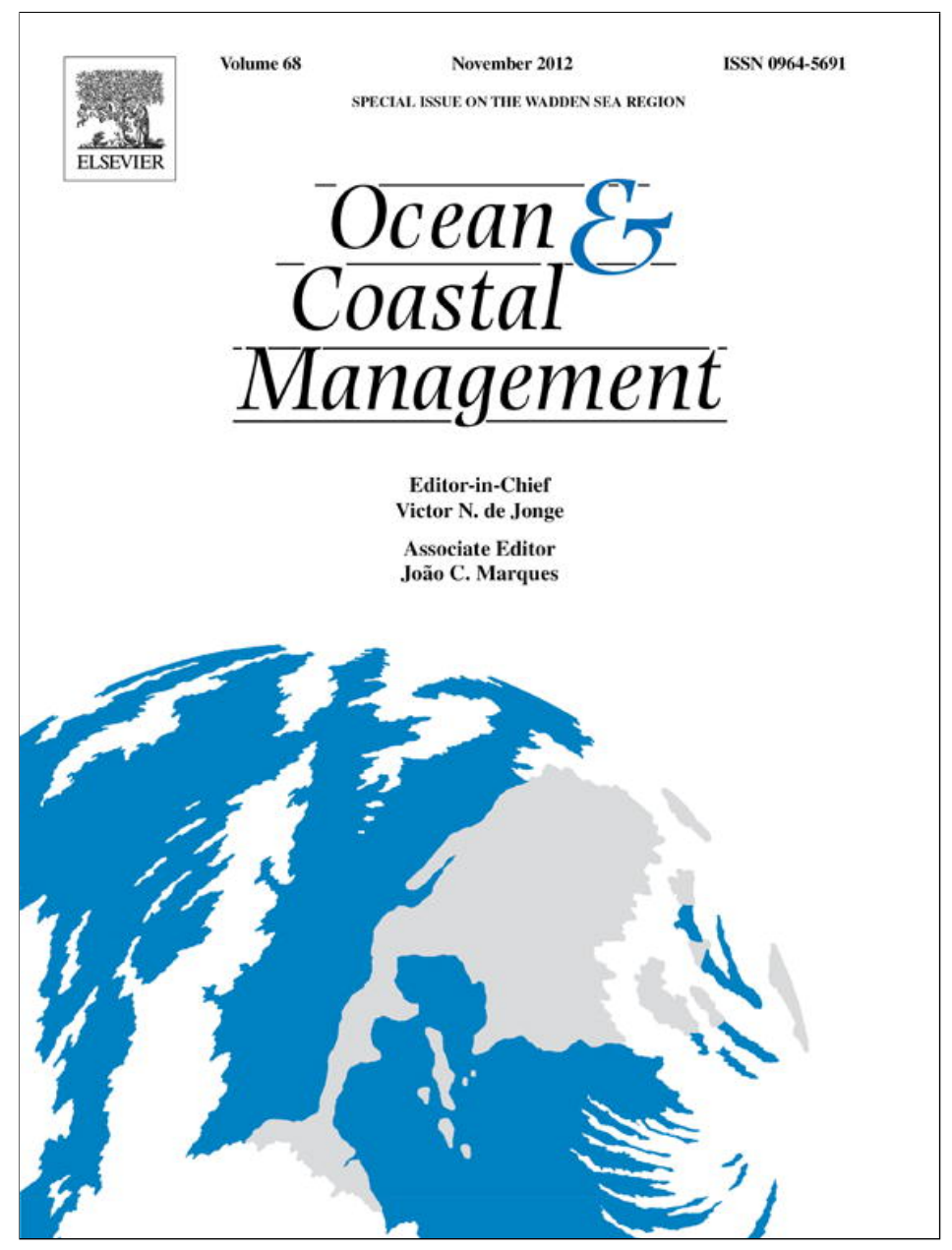

This article appeared in a journal published by Elsevier. The attached copy is furnished to the author for internal non-commercial research and education use, including for instruction at the authors institution and sharing with colleagues.

Other uses, including reproduction and distribution, or selling or licensing copies, or posting to personal, institutional or third party websites are prohibited.

In most cases authors are permitted to post their version of the article (e.g. in Word or Tex form) to their personal website or institutional repository. Authors requiring further information regarding Elsevier's archiving and manuscript policies are encouraged to visit:

http://www.elsevier.com/copyright 


\title{
Nonnative macrobenthos in the Wadden Sea ecosystem
}

\author{
Christian Buschbaum*, Dagmar Lackschewitz, Karsten Reise \\ Alfred Wegener Institute for Polar and Marine Research, Wadden Sea Station Sylt, Hafenstrasse 43, D-25992 List, Germany
}

\section{A R T I C L E I N F O}

Article history:

Available online 4 January 2012

\begin{abstract}
A B S T R A C T
An inventory in the Dutch-German-Danish Wadden Sea revealed a total of 66 nonnative (alien) taxa including 17 tentative cryptogenics in the brackish-marine macrobenthos until 2010, which is close to average compared with similar inventories from other coasts. Although the Wadden Sea is known for the largest sedimentary tidal flats in the world, most aliens encountered were fouling at harbor walls, pontoons in marinas, at hard structures for coastal defense but also in epibenthic mussel and oyster beds. Recent qualitative rapid assessments focusing on port localities have substantially improved knowledge on introduced species in the Wadden Sea. Nonnative species have pervaded algal and invertebrate communities, and the guild of suspension feeders became particularly strengthened by aliens which took advantage of a recent phase with relatively warm years. Most alien species were not directly introduced into the Wadden Sea but have spread secondarily from adjacent coasts with more active harbors or shellfish cultures. We suggest that aliens which have already established in the Wadden Sea ecosystem should be tolerated to avoid ongoing manipulations in eco-evolutionary developments in this protected nature area. Mitigation of the advancing tide of invasive aliens should focus on vector control (shipping and open aquacultures) as well as on early detection with attempts of eradication during the initial phase of invasions on a scale of the entire European Atlantic coast of which the Wadden Sea ecosystem is an integral part.
\end{abstract}

(c) 2011 Elsevier Ltd. All rights reserved.

\section{Introduction}

In the Wadden Sea, species richness of macrobenthic organisms is comparatively low because this shallow coastal region of the North Sea is young with respect to geological history and has been above sea level during glacial periods. When 7,500 years ago sea level rise slowed down, barrier islands, extensive sediment flats, salt marshes and estuaries did evolve in roughly the present position (Reise et al., 2010). During the last thousand years, most salt marshes have gradually been converted into arable land, small estuaries into freshwater streams, large estuaries into shipping canals, and many soft shores into artificial hard shores (Lotze et al., 2005). Still, this coastal region is characterized by the largest coherent tidal flats on earth, attracting huge flocks of foraging birds and young fish from the North Sea. Therefore, the Wadden Sea has come under joint nature protection by The Netherlands, Germany and Denmark, and most of the area is listed as a World Heritage Site, based on a unique and outstanding geomorphology, ecological and biological processes and biodiversity (CWSS, 2008). Success in

\footnotetext{
* Corresponding author. Tel.: +49 (0) 46519564228; fax: +49 (0) 4651956200.

E-mail addresses: Christian.Buschbaum@awi.de (C. Buschbaum), Dagmar. Lackschewitz@awi.de (D. Lackschewitz), Karsten.Reise@awi.de (K. Reise).
}

environmental management includes a ban to the hunting of seals and birds, restrictions to the harvest of shellfish, restoration of salt marshes, and reductions in the discharge of nutrients and hazardous substances.

On the other hand, the introduction of alien species proceeds almost unchecked and undermines the conservation target of the trilateral Wadden Sea Plan (CWSS, 2010) to keep the ecosystem as natural as possible. Global trade by shipping is accelerating the rate of introduction of nonnative species in marine communities of European coasts (Leppäkoski et al., 2002; Steftaris et al., 2005), and is in particular transforming estuarine ecosystems (Campbell et al., 2007; Carlton, 1989; Ruiz et al., 1997; Williams and Grosholz, 2008; Wolff, 1999). It is widely assumed that invasions by alien species are a leading cause of recent species extinctions which is mainly concluded from studies on oceanic islands and freshwater lakes (Fritts and Rodda, 1998; Gurevitch and Padilla, 2004; Lockwood, 2004). However, there is no evidence for extinctions of native species in marine environments caused by invaders (Wolff, 2000a; Gurevitch and Padilla, 2004; Briggs, 2010; Craig, 2010). Nevertheless, it is feared that regionally the biota may lose their integrity by the chronic infiltration of alien species, resulting in a global biotic homogenization of ecosystems (Lövei, 1997; McKinney and Lockwood, 1999; Olden et al., 2004). 
Furthermore, marine alien species are able to profoundly alter native communities, ecosystem functions and services (Ruiz et al., 1999; Occhipinti-Ambrogi and Galil, 2010; Ruesink et al., 2005), and this holds true for the European Wadden Sea as well (Reise et al., 2005; Nehring et al., 2009; Wolff et al., 2010). So far, no inventory of alien species has been accomplished for the trilateral Wadden Sea area, which is needed for joint management efforts. Up to now, only lists for national waters are available (Nehring and Leuchs, 1999; Jensen and Knudsen, 2005; Wolff, 2005; Gollasch and Nehring, 2006; Gittenberger et al., 2010) or summaries for the entire North Sea region (Reise et al., 1999; Gollasch et al., 2009). We here describe a rapid assessment at suspected hotspots of introductions in the German sector, combine this with results from a comparable survey in the Dutch sector (Gittenberger et al., 2010), as well as critically examined published records of alien species in order to compile a first inventory of nonnative macrobenthic species, comprising marine and brackish-water macroflora and macrofauna of the entire Wadden Sea area. Based on recent research, the integration of alien species in the ecosystem and options for their management in this protected nature area are discussed. We confine this study to macrobenthos because nonnative micro- and meiobenthos is not known for the Wadden Sea. For phyto- and zooplankton, coastal waters flowing through the Wadden Sea are not a meaningful subregion and lists for the entire North Sea should be consulted (i.e., Reise et al., 1999; Gollasch et al., 2009), and permanent resident and seasonally visiting fish of nonnative origin have not yet been recorded in the waters of the Wadden Sea.

\section{Methods}

\subsection{Rapid assessment}

To investigate the occurrence and distribution of nonnative macrobenthos along the German Wadden Sea coast, we visited in 2009 eight locations between July and October once and repeated the investigation in 2010 (Fig. 1). At each location three different habitats were examined resulting in a total number of 24 sites (Table 1). Despite a variety of habitats, we particularly focused in our study on artificial structures in harbors and marinas since these are known to be gateways for alien newcomers with suitable habitats for establishment (Arenas et al., 2006; Ashton et al., 2006; Cohen et al., 2005; Minchin, 2007a; Gittenberger et al., 2010). Search and sampling by one to two experts lasted between 1 and $2 \mathrm{~h}$ at each site and 2-4 h per locality, depending on habitat size and heterogeneity. Most species were detected within the first

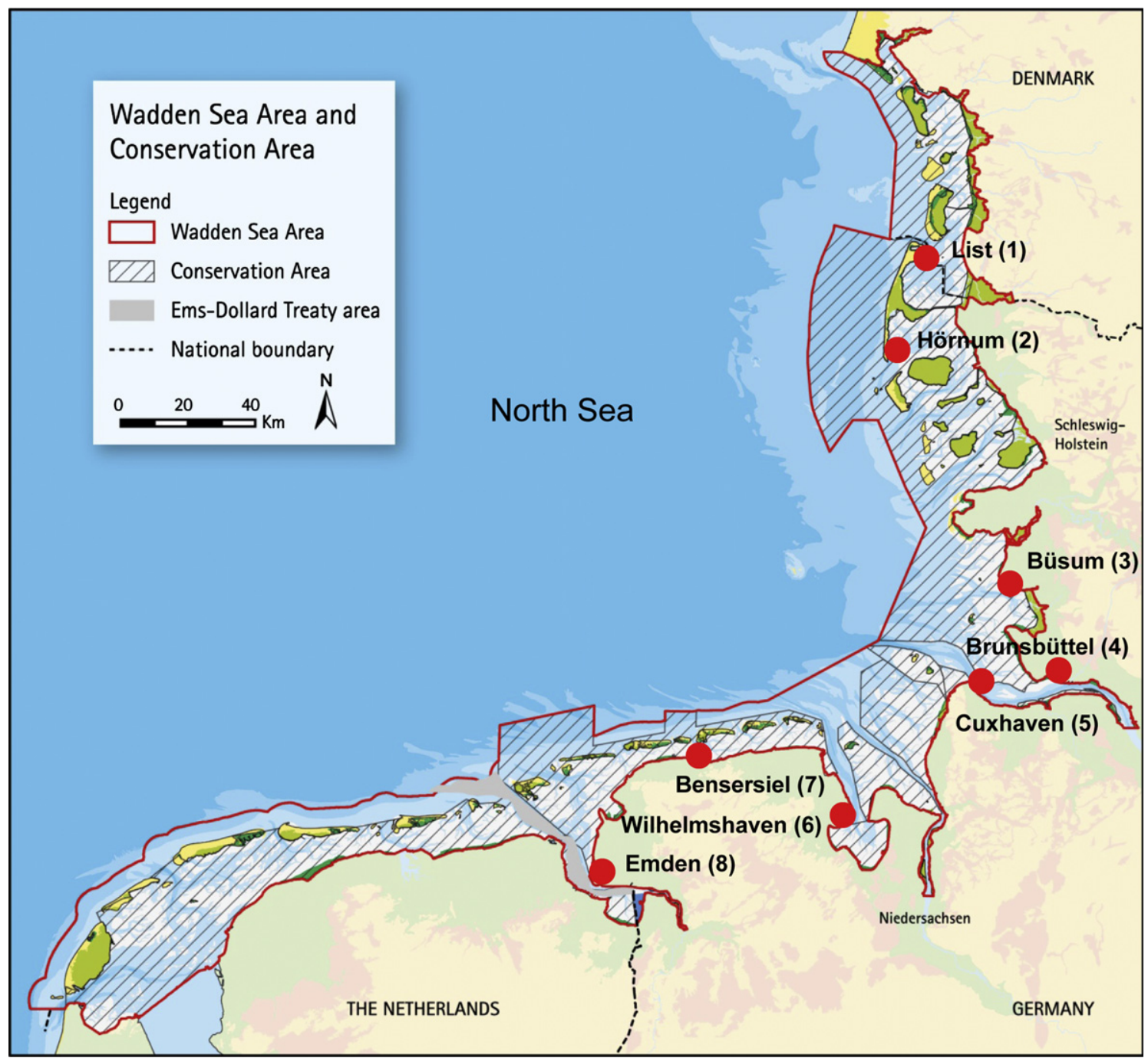

Fig. 1. The European Wadden Sea Area (surrounded by a red line) according to Marencic (2009) and investigated locations (see Table 1) of the rapid assessment of neobiota along the German Wadden Sea coast. 
Table 1

Information on the locations and sites surveyed during the rapid assessment study at the German Wadden Sea coast in 2009 and 2010 . The surface salinities represent the maximum values measured during investigations.

\begin{tabular}{|c|c|c|c|c|}
\hline \multirow[t]{2}{*}{ Locations (8) } & \multicolumn{2}{|c|}{ Location coordinates } & \multirow{2}{*}{$\frac{\text { Salinity }}{2009 / 2010}$} & \multirow[t]{2}{*}{ Sites surveyed (24) } \\
\hline & Latitude & Longitude & & \\
\hline \multirow[t]{3}{*}{ 1. List } & $54^{\circ} 59.41^{\prime}$ & $8^{\circ} 23.05^{\prime}$ & \multirow[t]{3}{*}{$30 / 31 \mathrm{psu}$} & Oyster farm and shallow sediments south of List \\
\hline & $55^{\circ} 00.59^{\prime}$ & $8^{\circ} 26.25^{\prime}$ & & Harbor pontoons for leisure boats \\
\hline & $55^{\circ} 02.00^{\prime}$ & $8^{\circ} 26.22^{\prime}$ & & Harbor mole and embankments \\
\hline \multirow[t]{3}{*}{ 2. Hörnum } & $54^{\circ} 45.37^{\prime}$ & $8^{\circ} 17.45^{\prime}$ & \multirow[t]{3}{*}{$30 / 30 \mathrm{psu}$} & Harbor pontoons for leisure boats \\
\hline & $54^{\circ} 45.38^{\prime}$ & $8^{\circ} 17.48^{\prime}$ & & Harbor mole and embankments \\
\hline & $54^{\circ} 45.57^{\prime}$ & $8^{\circ} 17.59^{\prime}$ & & Sandy beach sediment north of harbor \\
\hline \multirow[t]{3}{*}{ 3. Büsum } & $54^{\circ} 07.24^{\prime}$ & $8^{\circ} 51.52^{\prime}$ & \multirow[t]{3}{*}{$25 / 24 \mathrm{psu}$} & Harbor pontoons for leisure boats \\
\hline & $54^{\circ} 07.27^{\prime}$ & $8^{\circ} 52.02^{\prime}$ & & Harbor mole and embankments \\
\hline & $54^{\circ} 07.31^{\prime}$ & $8^{\circ} 52.09^{\prime}$ & & Mud and sand tidal area in northeastern harbor edge \\
\hline \multirow{3}{*}{ 4. Brunsbüttel } & $53^{\circ} 53.17^{\prime}$ & $9^{\circ} 07.17^{\prime}$ & \multirow[t]{3}{*}{$10 / 6$ psu } & Breakwater into the river Elbe \\
\hline & $53^{\circ} 53.21^{\prime}$ & $9^{\circ} 07.20^{\prime}$ & & Tidal mud flat along the river bank \\
\hline & $53^{\circ} 54.00^{\prime}$ & $9^{\circ} 09.12^{\prime}$ & & Embankment of the Kiel-Canal behind the sluice \\
\hline \multirow[t]{3}{*}{ 5. Cuxhaven } & $53^{\circ} 53.35^{\prime}$ & $8^{\circ} 41.09^{\prime}$ & \multirow[t]{3}{*}{$20 / 18 \mathrm{psu}$} & Breakwaters into the Elbe estuary at the 'Kugelbake' \\
\hline & $53^{\circ} 53.33^{\prime}$ & $8 \circ 41.05^{\prime}$ & & Sandy tidal flats at the northern tip ('Kugelbake') \\
\hline & $53^{\circ} 52.32^{\prime}$ & $8^{\circ} 42.16^{\prime}$ & & Harbor pontoons for leisure boats \\
\hline \multirow[t]{3}{*}{ 6. Wilhelmshaven } & $53^{\circ} 30.35^{\prime}$ & $8^{\circ} 07.45^{\prime}$ & \multirow[t]{3}{*}{$30 / 30 \mathrm{psu}$} & Breakwaters into the Jadebusen \\
\hline & $53^{\circ} 30.39^{\prime}$ & $8^{\circ} 07.54^{\prime}$ & & Sandy tidal areas south of the city \\
\hline & $53^{\circ} 30.55^{\prime}$ & $8^{\circ} 08.59^{\prime}$ & & Harbor pontoons for leisure boats (Nassauhafen) \\
\hline \multirow[t]{3}{*}{ 7. Bensersiel } & $53^{\circ} 40.40^{\prime}$ & $7^{\circ} 34.16^{\prime}$ & \multirow[t]{3}{*}{$30 / 30 \mathrm{psu}$} & Harbor pontoons for leisure boats \\
\hline & $53^{\circ} 40.47^{\prime}$ & $7^{\circ} 33.58^{\prime}$ & & Sandy tidal flats and beach \\
\hline & $53^{\circ} 40.56^{\prime}$ & $7^{\circ} 33.59^{\prime}$ & & Breakwater along the ferry canal \\
\hline \multirow[t]{3}{*}{ 8. Emden } & $53^{\circ} 20.36^{\prime}$ & $7^{\circ} 11.23^{\prime}$ & \multirow[t]{3}{*}{$17 / 10 \mathrm{psu}$} & Harbor pontoons for leisure boats \\
\hline & $53^{\circ} 20.05^{\prime}$ & $7^{\circ} 11.12^{\prime}$ & & Breakwaters and dike revetment at the river Ems \\
\hline & $53^{\circ} 20.05^{\prime}$ & $7^{\circ} 11.15^{\prime}$ & & Muddy and sandy areas along the northern river bank \\
\hline
\end{tabular}

15 min, and a survey was considered as complete when all subhabitats had been visited and no more than one additional species were found for at least $30 \mathrm{~min}$. Organisms attached to artificial structures such as floating pontoons (being independent of the tidal cycle) or harbor walls were sampled with scrapers. Sediments were dug up with a spade during low tide and sieved through a $1 \mathrm{~mm}$ mesh. In our experience, the focus on the intertidal as well as the shallow subtidal zone accessible to wading during low tide, together with the underside of floating objects, captures the spectrum of alien macrobenthic species in the Wadden Sea fairly well. Most organisms were identified in the field. Unknown species and minute organisms were preserved in $75 \%$ ethanol or transported alive to the laboratory and identified using optical appliance. Salinity of surface waters was measured once during sampling to get a rough estimate. Similar to other rapid assessments with a non-quantitative search-and-sample strategy (cited above), we aimed to detect as many alien species as possible, combining an efficient use of given resources in manpower and available time with the highest gain of information.

\subsection{Compiling an overview of alien macrobenthos in the Wadden Sea}

To achieve a valid and comprehensive list of nonnative and cryptogenic species (sensu Carlton, 1996) for the entire Wadden Sea, we performed an extensive literature study focusing on recent records to ensure the current distribution in the area. The distinction between nonnative and cryptogenic is often confounded by uncertainties. Except for the most recent records we followed Wolff (2005) in assigning taxa to these tentative categories. Only species assumed to originate outside the European Atlantic coasts are considered as introduced nonnative organisms. We included species whose status is still debated, but rejected conspicuous species with single records only, assuming these not (yet) to be established, i.e., the crabs Limulus polyphemus and Callinectes sapidus or the flatfish Trinectes maculatus. Likewise we did not list species above mean high-tide line, such as the saltmarsh spermatohyte Cotula coronopifolia.

The Wadden Sea can neither geographically nor ecologically strictly be separated from the North Sea and the incoming rivers.
We adopted the geographical definition of the Wadden Sea Area given by Marencic (2009) in Fig. 1. Boundaries in rivers are the transitions between freshwater and brackish water. Seaward the boundary is at three nautical miles offshore or at the outer limit of the conservation area in two cases. Although islands are part of the Wadden Sea Area, our assessment does not cover their freshwater and terrestrial habitats. Likewise, pelagic species are not included because these are better treated at the scale of the entire North Sea.

\section{Results}

\subsection{Rapid assessment survey}

The rapid assessment of alien species along the German Wadden Sea coast at eight locations comprising 24 sites yielded 25 and 30 species in 2009 and 2010, respectively. In total, we identified 34 nonnative or cryptogenic macrobenthic species covering 7 plants and 27 invertebrates (Table 2). Five species were encountered which have not been reported from the area so far. We found the cute tanaid crustacean Sinelobus stanfordi at the entrance of the Kiel-Canal in 2009 and 2010, and occurring also in the harbor of Emden in 2010. In 2009, we detected the bryozoan Tricellaria inopinata, new to the northern and southern German Wadden Sea, and in 2010 Bugula neritina in the harbor of Hörnum/Sylt. Two new alien red algae were recognized in 2010, namely Ceramium cimbricum and Antithamnionella ternifolia. Only the latter was found in natural habitats.

The highest number of alien species (26) was found at two locations near the island of Sylt where salinity is high (Tables 1 and 2 : location $1+2$ ), whereas only few occurred at the entrance of the Kiel-Canal (Brunsbüttel) and in the Ems estuary where salinity is low (Tables 1 and 2: location $4+8$ ). An oyster farm with annual imports of Crassostrea gigas and mussel cultures with imported Mytilus edulis from the British Isles may contribute to the amount of aliens near Sylt. The barnacle Balanus improvisus was observed at all locations and not more than 9 species were found at more than half of the locations. The majority of species (22) was found at 1-3 locations only, and ten were found either in 2009 or 2010. Thus, 
Table 2

Alien and cryptogenic species recorded at 8 locations during the rapid assessment surveys on neobiota along the German Wadden Sea coast in 2009 and 2010. Location 1 List/Sylt, 2 Hörnum/Sylt, 3 Büsum, 4 Brunsbüttel, 5 Cuxhaven, 6 Wilhelmshaven, 7 Bensersiel, 8 Emden (for further details see Fig. 1 and Table 1). Absent (-)/present $(+)$ in $2009 / 2010$, respectively. No entry: not found at locality.

\begin{tabular}{|c|c|c|c|c|c|c|c|c|}
\hline Location & 1 & 2 & 3 & 4 & 5 & 6 & 7 & 8 \\
\hline \multicolumn{9}{|l|}{ Phaeophyceae } \\
\hline Sargassum muticum & $+1+$ & $+1+$ & & & & & & \\
\hline Chlorophyceae & & & & & & & & \\
\hline $\begin{array}{l}\text { Codium fragile } \\
\text { tomentosoides }\end{array}$ & $+1-$ & & & & & & & \\
\hline \multicolumn{9}{|l|}{ Rhodophyceae } \\
\hline $\begin{array}{l}\text { Antithamnionella } \\
\text { ternifolia }\end{array}$ & $-1+$ & & & & & & & \\
\hline Ceramium cimbricum & & $-1+$ & & & & & & \\
\hline $\begin{array}{l}\text { Gracilaria } \\
\quad \text { vermiculophylla }\end{array}$ & $+1+$ & $+1+$ & $+1+$ & & $-1+$ & & $+1+$ & \\
\hline $\begin{array}{l}\text { Polysiphonia harveyi } \\
\text { Tracheophyta }\end{array}$ & & $-1+$ & & & & $-1+$ & & \\
\hline Spartina anglica & & & $+1+$ & & & & $+1+$ & \\
\hline Cnidaria & & & & & & & & \\
\hline $\begin{array}{l}\text { Cordylophora caspia } \\
\text { Mollusca }\end{array}$ & & & & $-1+$ & & & & \\
\hline Crepidula fornicata & $+1+$ & $+1+$ & & & & $+1+$ & $-1+$ & \\
\hline Crassostrea gigas & $+1+$ & $+1+$ & $+1+$ & & $+1+$ & $+1+$ & $+1+$ & $+1+$ \\
\hline Ensis americanus & $-1+$ & $+1+$ & & & $-1+$ & & $+1-$ & \\
\hline Mya arenaria & $+1+$ & $+1-$ & $-1+$ & & $+1+$ & $-1+$ & $+1+$ & \\
\hline Mytilopsis leucophaeta & & & & $-1+$ & & & & \\
\hline Petricola pholadiformis & & & & & & $-1+$ & & \\
\hline Teredo navalis & $+1+$ & & & & $+1+$ & & & \\
\hline Polychaeta & & & & & & & & \\
\hline Nereis virens & $+1-$ & $+1-$ & $+1+$ & & $+1-$ & & & \\
\hline Tharyx killariensis & $-1+$ & & & & & & & \\
\hline Crustacea & & & & & & & & \\
\hline Austrominius modestus & $+1+$ & $+1+$ & $+1+$ & & $+1+$ & $+1+$ & $+1+$ & \\
\hline $\begin{array}{l}\text { Balanus improvisus } \\
\text { Sinelobus stanfordi }\end{array}$ & $-1+$ & $-1+$ & $+1+$ & $\begin{array}{l}+1+ \\
+1+\end{array}$ & $+1+$ & $-1+$ & $-1+$ & $\begin{array}{l}+1+ \\
-1+\end{array}$ \\
\hline Caprella mutica & $+1+$ & $+1+$ & $-1+$ & & & & & \\
\hline Gammarus tigrinus & & & & $+1+$ & & & & \\
\hline Eriocheir sinensis & & & & $+1+$ & & & & \\
\hline Hemigrapsus takanoi & $+1+$ & $-1+$ & $-1+$ & & $+1+$ & $+1+$ & $+1+$ & \\
\hline Hemigrapsus sanguineus & $+1+$ & $+1+$ & $+1-$ & & $+1-$ & $+1-$ & $+1-$ & \\
\hline $\begin{array}{l}\text { Palaemon macrodactylus } \\
\text { Insecta }\end{array}$ & & & $+1-$ & & & $-1+$ & & $-1+$ \\
\hline Telmatogeton japonicus & $-1+$ & & $+1+$ & $+1+$ & $+1+$ & & $+1+$ & $-1+$ \\
\hline Bryozoa & & & & & & & & \\
\hline Bugula neritina & & $-1+$ & & & & & & \\
\hline Bugula stolonifera & & $-1+$ & & & & $-1+$ & & \\
\hline $\begin{array}{l}\text { Tricellaria inopinata } \\
\text { Tunicata }\end{array}$ & $+1-$ & $+1-$ & & & & $+1-$ & & \\
\hline Aplidium c.f. glabrum & $+1+$ & $+1-$ & & & & $+1-$ & & \\
\hline Botryllus schlosseri & $+1+$ & $+1+$ & & & & $-1+$ & & \\
\hline Molgula manhattensis & $+1+$ & $+1+$ & $+1+$ & & & $-1+$ & $+1+$ & \\
\hline Styela clava & $+1+$ & $+1+$ & & & & $+1+$ & & \\
\hline Species in total & 22 & 21 & 13 & 7 & 11 & 16 & 12 & 5 \\
\hline
\end{tabular}

alien species tend to show a rather uneven spatiotemporal distribution along the coast.

\subsection{Alien species inventory}

Up to 2010, a total of 66 nonnative (49) and cryptogenic (17) species of the macrobenthos have been recorded for the entire Wadden Sea (Table 3). The most diverse higher taxa are crustaceans (18 species), followed by macroalgae (14), polychaetes ( 8 ), mollusks (7), tunicates (6) and cnidarians (5). In the Dutch and German sectors 57 and 52 species respectively, have been recorded. In the Danish sector no specific assessment has been conducted and only 19 alien species are on the record there. The majority of the species presented in Table 3 can be regarded as established, however, for 8 of them the records are still very recent (2009 and/or 2010). Since the closure of the Zuiderzee, the nonnative snail Corambe obscura has not been recorded anymore (Swennen and Dekker, 1995) and should be regarded as extinct for the Wadden Sea.

Most aliens in the Wadden Sea are marine species. Sixteen are either brackish water species or are regularly present under brackish conditions in addition to marine or freshwater. Two species cover the entire range from freshwater to marine (the eel parasite Anguillicola crassus and the crab Eriocheir sinensis). The most important donor regions are the western Pacific (28 species) followed by the western Atlantic (16 species). The origin of at least $25 \%$ is unknown or uncertain.

Most nonnatives found in the Wadden Sea have been encountered at other European coasts, mostly southwest of the Wadden Sea such as France (13 species), British Isles (16) and the Dutch Delta area (15) before arriving in the Wadden Sea. Only 8 are known to have entered directly this region and from there spread or were transported to adjacent coasts. Examples of the latter are the intentionally introduced cordgrass Spartina anglica and the Pacific oyster $C$. gigas, both imported from the British Isles but natural spread along coasts occurred in both species as well (Reise et al., 2005). The Chinese crab E. sinensis was first recorded in Europe in a tributary of the river Weser which debouches into the Wadden Sea. From there this crab has spread to other parts of Europe, although there is also genetic evidence for multiple introductions (Wang et al., 2009). The American razor clam Ensis (directus) americanus presumably arrived with ballast water released in the German Bight in front of the Wadden Sea or near the western Dutch Wadden Sea (Wolff, 2005). The mussel parasite Mytilicola intestinalis and the eel parasite $A$. crassus were first encountered near the Elbe estuary in the central Wadden Sea (Elsner et al., 2011; Koops and Hartmann, 1989). Three other species were first found in the former Zuiderzee which was an embayment of the Wadden Sea until its conversion into land and a freshwater reservoir since 1932 (Wolff, 2005). Such direct introductions account for only about $12 \%$ of the nonnative and cryptogenic species.

Only 9 of the macrobenthic aliens recorded in the Wadden Sea are dwelling in sediments. All others are fouling on artificial hard substrates of harbors and coastal defense, attach to biogenic hard structures such as mussel or oyster beds or are closely associated with these for hiding and feeding. Often first observations are from artificial structures and from there a spread to natural substrates has followed, i.e., Caprella mutica, Styela clava, Aplidium cf. glabrum and Hemigrapsus spp. (own observations).

\section{Discussion}

Rapid qualitative assessments of alien species with a focus on harbors, marinas and shellfish farming have substantially improved the knowledge on the occurrence and spatial distribution of nonnatives and cryptogenics in the Wadden Sea. In the discussion below we first compare the inventory to those of other coasts, consider management implications of secondary introductions and alien fouling organisms which prevail in the Wadden Sea, and suggest improvements for rapid assessments. Concerning nature management in the protected Wadden Sea we argue to tolerate the already established alien species, and to focus on vector control and eradications prior to a firm establishment of an alien species.

\subsection{Inventory of alien species in the Wadden Sea}

The inventory of nonnative and presumably nonnative (cryptogenic) macrobenthic organisms in the brackish and marine parts of the Wadden Sea comprised a total of 66 taxa until 2010.

As in other coastal studies, the macrobenthos is the group comprising most nonnative species. In addition, the North Sea coastal waters flowing through the Wadden Sea contain about 14 


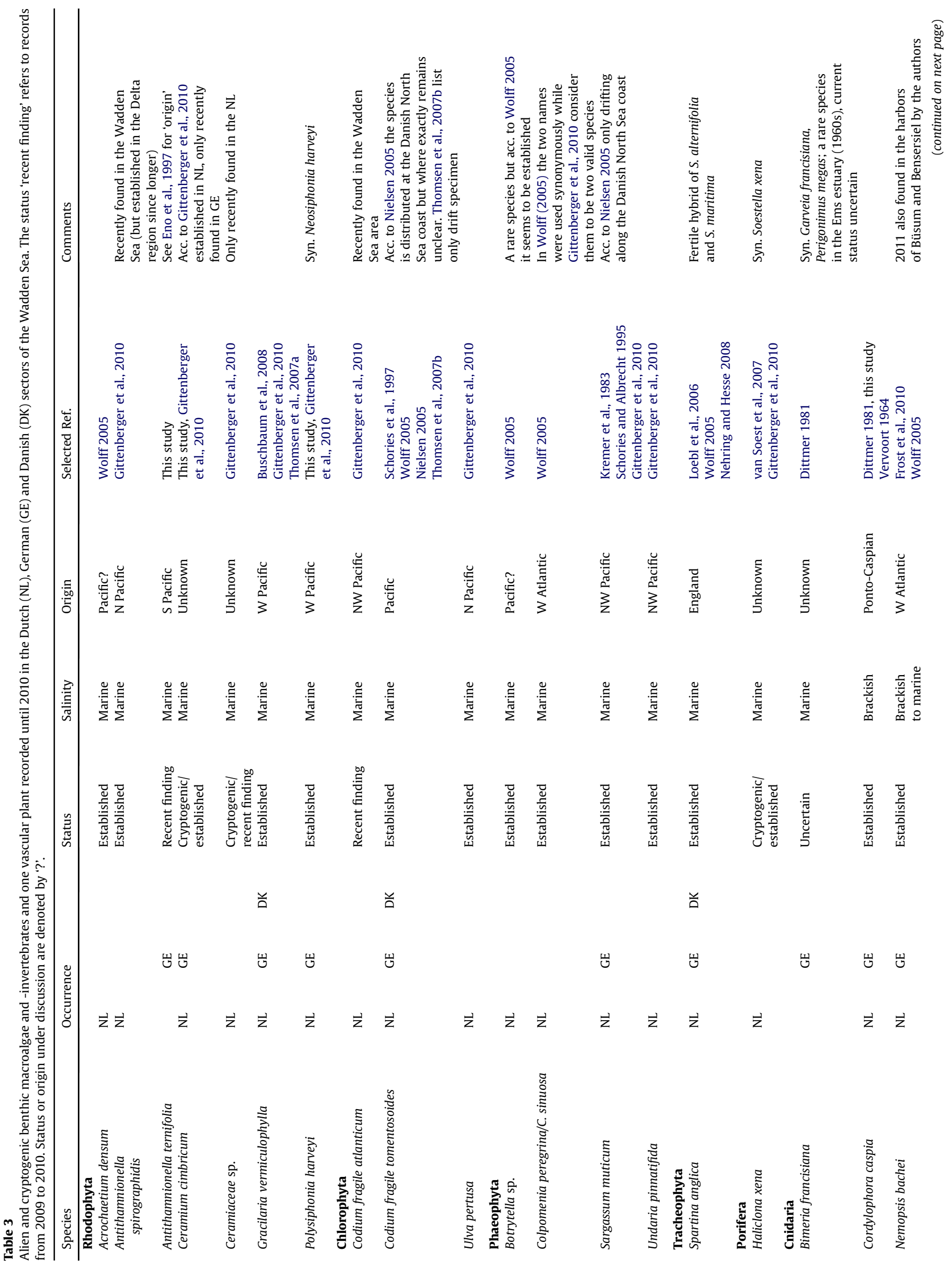




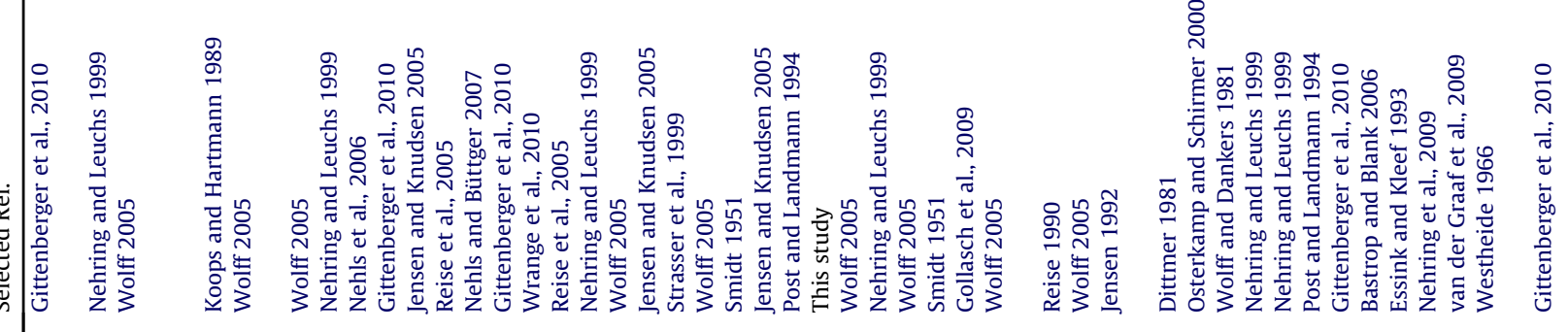

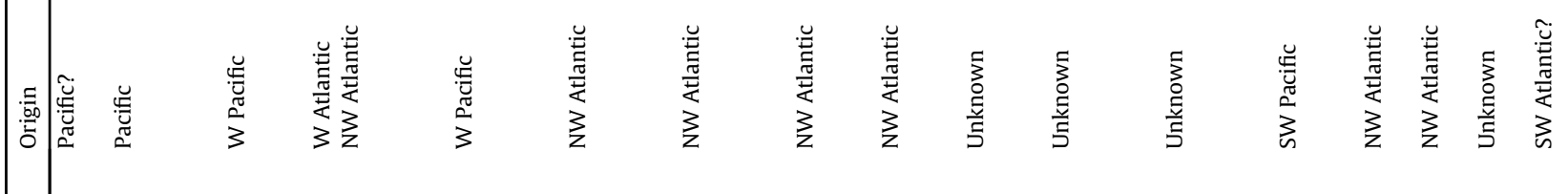

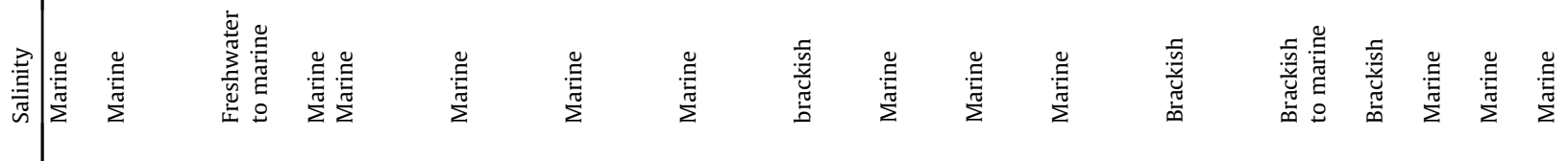

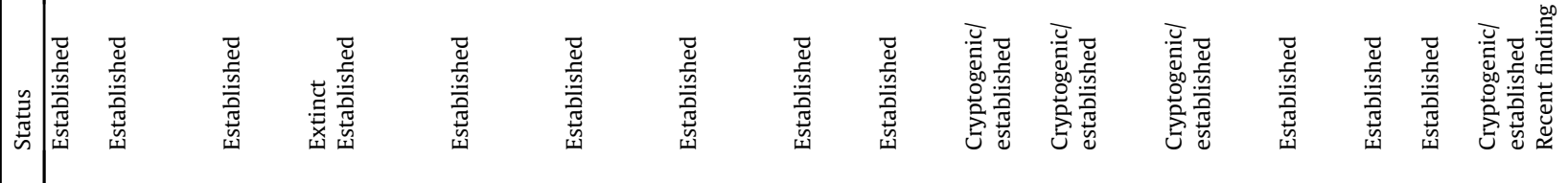

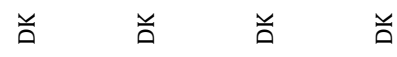
高
高

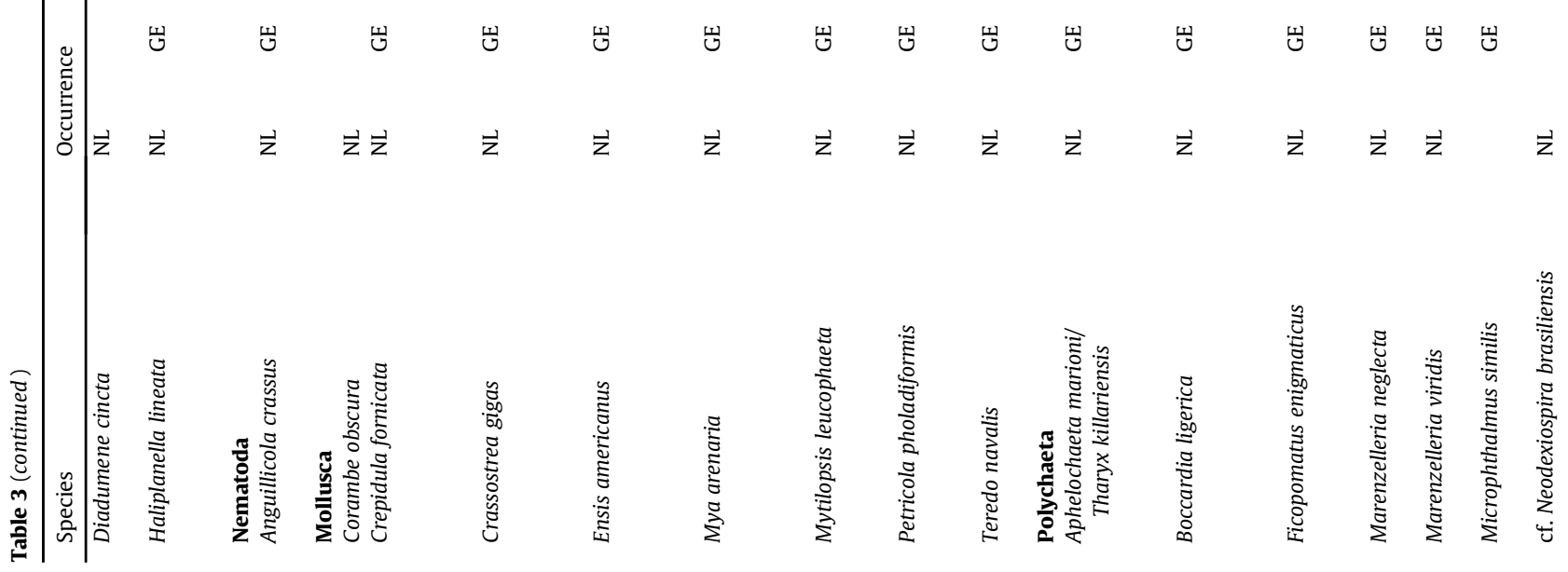



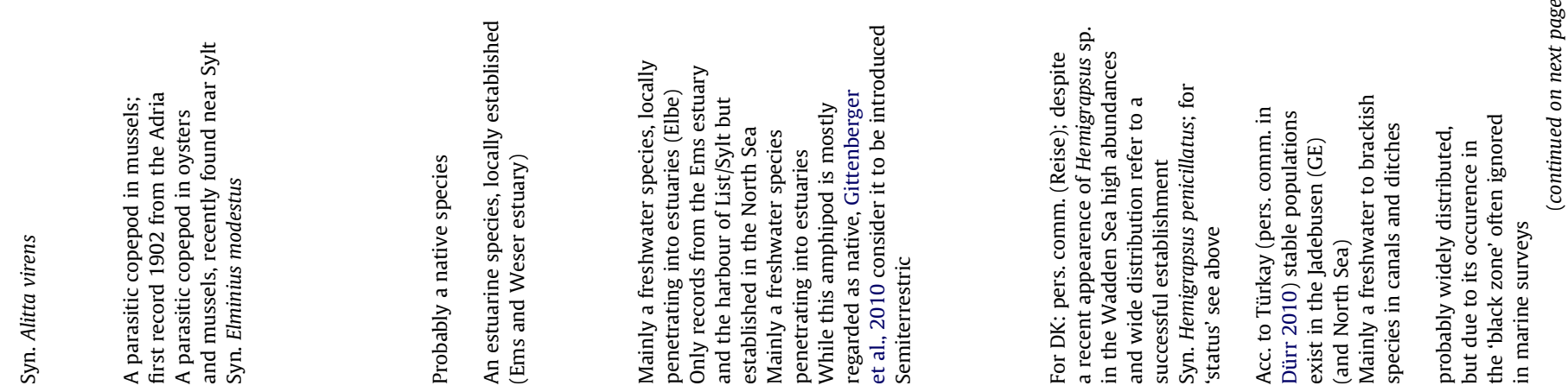

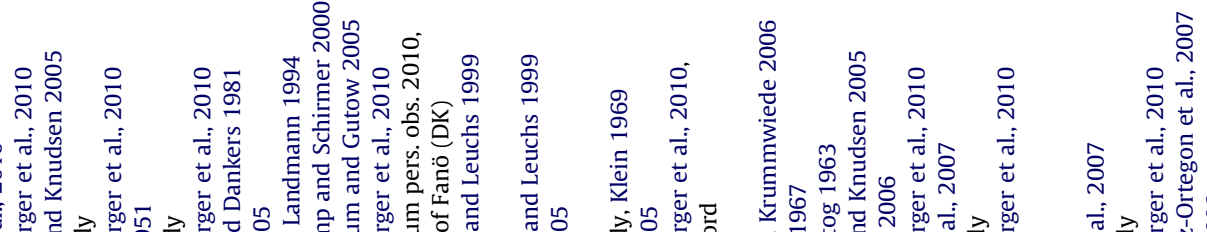

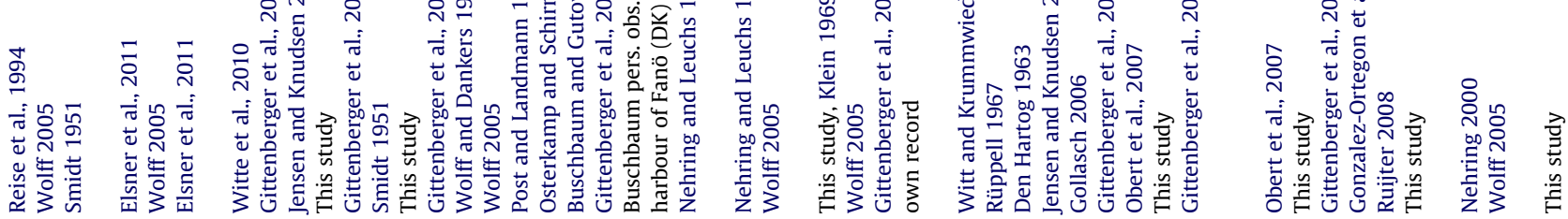

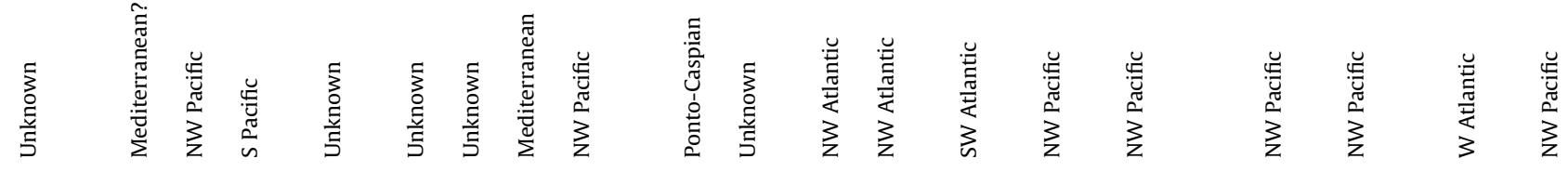

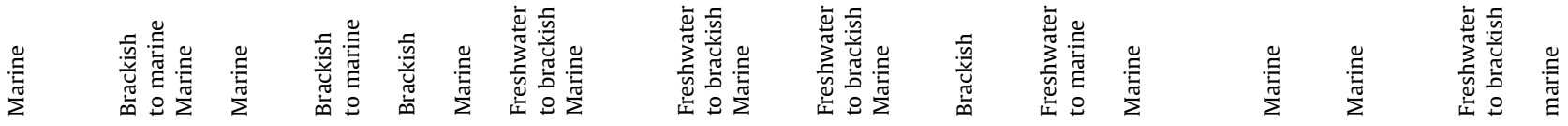

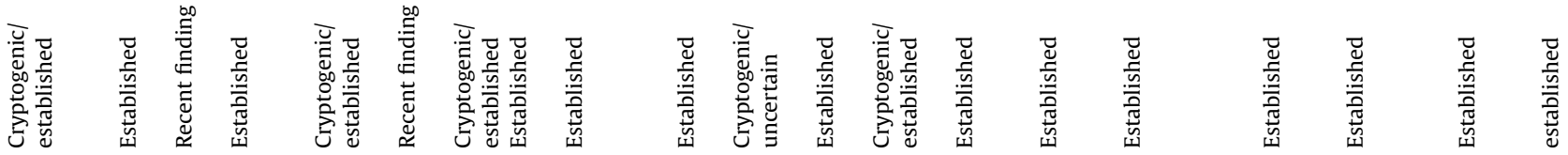

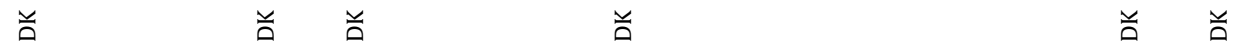

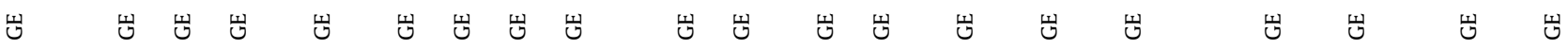

$\begin{array}{lllllllllllllllll}\vec{z} & \vec{z} & \vec{z} & \vec{z} & \vec{z} & \vec{z} & \vec{z} & \vec{z} & \vec{z} & \vec{z} & \vec{z} & \vec{z} & \vec{z} & \vec{z} & \vec{z} & \vec{z}\end{array}$

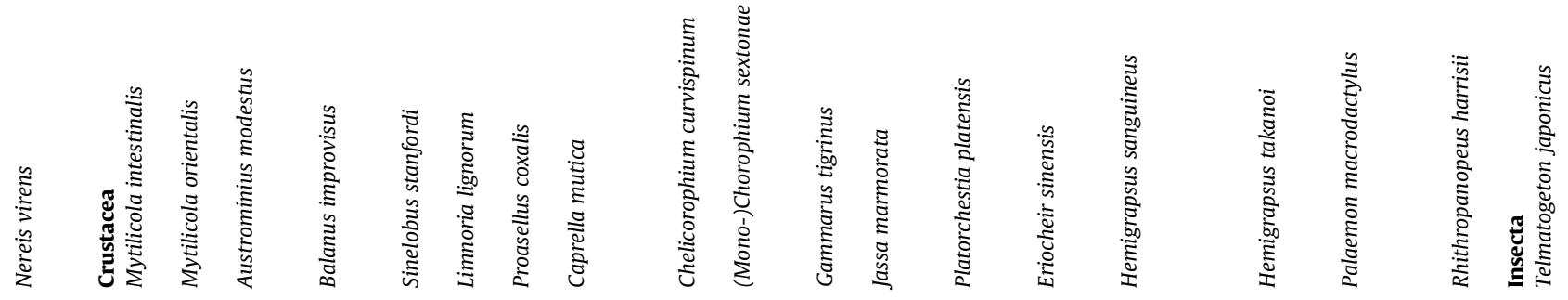




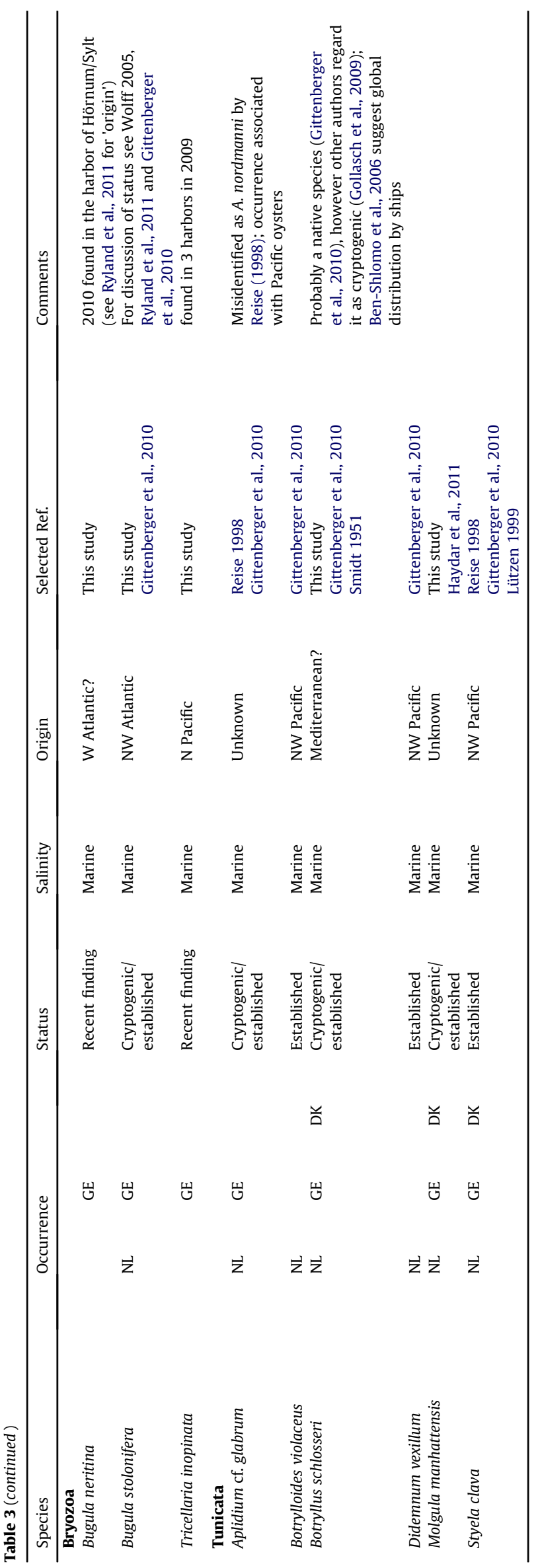

phytoplankton and two zooplankton nonnative taxa (Gollasch et al., 2009; Reise et al., 1999) while permanent populations of alien fish are not yet known. The number of alien species in the Wadden Sea is close to average when compared to similar assessments in other coastal regions (Table 4). However, coastal regions with more active ports and/or shellfish farming (i.e., San Francisco Bay, Port Phillip Bay) or Mediterranean coasts adjacent to the Suez Canal (Galil, 2009) surpass the Wadden Sea in the number of nonnative taxa. In a comprehensive inventory of nonnative species in the coastal Netherlands, Wolff (2005) already pointed out that more aliens occurred in the small Oosterschelde estuary which is the centre of the Dutch shellfish culture than in the much larger Dutch Wadden Sea.

For managing the advancing flood of alien invasions it is an important finding that only a few nonnative species were directly introduced into the Wadden Sea, while most have arrived secondarily, either by natural dispersal from sites of primary introduction, by shellfish translocations, by regional shipping along the coasts of Western Europe or through inland canals and rivers. Wasson et al. (2001) observed a high number (56) of introduced invertebrate species in Elkhorn Slough, a small estuary lacking international shipping and located about $150 \mathrm{~km}$ down the shore from San Francisco Bay, which is the estuary with the highest load of alien invertebrate species, worldwide. Similar to the Wadden Sea, secondary immigrations have occurred from nearby hotspots of transoceanic shipping and shellfish farming, while direct introductions from overseas played a minor role in the invasion history of Elkhorn Slough. Consequently, effective prevention of further introductions into the Wadden Sea which is much larger than Elkhorn Slough but is also located downstream of coasts receiving more introductions, calls for concerted controls of oversea transports on a larger scale. Thus, management of alien species requires a coordinated strategy for the entire European Atlantic coast.

Also important to the prevention of alien invasions is the observation that man-made hard structures constitute a major gateway and may provide stepping stones for further spread along the sedimentary coast of the Wadden Sea. The almost unlimited sprawl of artificial hard substrates (i.e., harbor walls, pilings, pontoons in marinas, buoys, breakwaters, dams, petrified shorelines, garbage) offers plenty of habitats for fouling nonnative organisms introduced either on ship hulls or by transfers of cultured shellfish (Reise and Buschbaum, 2007). Prospects to restrict this highway for the spread of aliens are rather dim with the current proliferation of offshore wind parks in the North Sea. However, coastal defense in the Wadden Sea offers a large potential for substituting or covering hard structures by sand nourishments (Reise and Lackschewitz, 2003).

\subsection{Rapid assessments focused on alien species}

To effectively manage the issue of nonnative marine species, sound knowledge on the alien species already present is required (Campbell et al., 2007). Otherwise the success of precautionary measures to prevent further introductions cannot be measured. In the Wadden Sea, such surveys focused on harbors and marinas with their surroundings (Gittenberger et al., 2010; this study) which in the past have been neglected in benthic studies. This effort has complemented previous lists of alien species which were merely based on chance observations. Both rapid assessments of alien species (RAAS) performed at the German coast in 2009 and 2010 revealed a rather patchy occurrence of aliens among sampling sites and years. Thus, a necessary improvement would be to increase the number of sites to be investigated and to continue such surveys on an annual basis. 
Table 4

Nonnative (including cryptogenics) macrobenthic invertebrate and algal species found in nine selected coastal regions. Species numbers were obtained from the lists of nonnatives provided in the literature.

\begin{tabular}{lcccl}
\hline Coastal region & Invertebrates & Algae & Total & Source \\
\hline Wadden Sea (North Sea) & 51 & 14 & 65 & This study (without cordgrass Spartina anglica) \\
Dutch Delta area (North Sea) & 55 & 20 & 75 & Wolff (2005); Faasse and Lighthart (2009) \\
Baltic Sea & 30 & 9 & 39 & Paavola et al. (2005) \\
Ireland (NE-Atlantic) & 28 & 15 & 43 & Minchin (2007b) \\
Northern Adriatic (Mediterranean Sea) & 37 & 12 & 49 & Occhipinti-Ambrogi et al. (2011) \\
Chesapeake Bay (NW-Atlantic) & 37 & 4 & 41 & Ruiz et al. (2000) \\
Puget Sound and Straits (NE-Pacific) & 65 & 3 & 68 & Wonham and Carlton (2005) \\
San Francisco Bay (NE-Pacific) & 105 & 5 & Cohen and Carlton (1995); Wasson et al. (2001) \\
Port Phillip Bay (S-Australia) & 90 & 67 & 157 & Hewitt et al. (2004); Ruiz et al. (2000) \\
\hline
\end{tabular}

Relatively little time is required for field campaigns. However, identification of new alien species is often a time consuming endeavor and depends on taxonomical experience and the cooperation of specialists. A potential bottleneck for rapid assessments is to find scientists sufficiently trained in species identifications, additionally having knowledge on alien species spreading in other regions of Europe and thus are likely to appear sooner or later in the Wadden Sea as well. If RAAS are conducted to detect introductions of nonnatives at an early stage of invasion which would still allow effective eradication or control (see Simberloff, 2009), it would be necessary to perform such regular surveys in a well coordinated program along all European Atlantic coasts with a focus on ports and shellfish culture sites. As mentioned above, such a wide scale effort is essential because of the prevalence of secondary alien arrivals in the Wadden Sea.

\subsection{How to manage alien species in the Wadden Sea?}

Several species from native oysters to gray whales have been lost in the past from the Wadden Sea due to habitat loss, hunting and fishery (Reise, 1990; Wolff, 2000b), and there is consensus that environmental management should facilitate the return of lost species. Should management also try to get rid of the many species that have been intentionally or unintentionally introduced from overseas? Is this desirable and is it feasible? Since the issue of species introductions has advanced to an active discipline of research and management in the 1990s, the importance of regulating alien species invasions has been fiercely debated (for a recent example see Davis et al. (2011) with subsequent correspondence and letters). While one side points out that species of a nonnative origin should not be generally dismissed because not all constitute a threat and many may be beneficial as a resource or in the ecosystem, the other side insists on "aggressive intervention" against the "most severe and fastest growing threat to biological diversity" (Lambertini et al., 2011).

Although the political stage has been set by Article $8(\mathrm{~h})$ of the Rio Convention on Biological Diversity adopted in 1992 ("... as far as possible and as appropriate, to prevent the introduction of, control and eradicate those alien species which threaten ecosystems, habitats or species.") and further specified by Guiding Principles on Invasive Alien Species in 2002 (CBD, www.biodiv.org), regional management should be adjusted to the specific conditions of the Wadden Sea. In spite of the numerous alien species already accumulated in the Wadden Sea, we know of no native species which have gone extinct because of these invaders (Wolff, 2000a; own observations). The scenario of a few alien winners replacing many native losers (McKinney and Lockwood, 1999) does not fit. We suggest that extinctions by competitive exclusion are rather unlikely at a coast with high habitat heterogeneity and gradients in depth, salinity and substrates as well as with temporarily empty habitats due to frequent disturbances (Armonies and Reise, 2003). In addition, a rich natural supply of nutrients and food from rivers and the North Sea, enhanced by anthropogenic eutrophication, may ease the accommodation of alien species. Particularly inviting are 'alien' substrates introduced for coastal defense, shipping or recreational purposes for introduced alien species (see chap. 4.1). Taken together, these natural characteristics and man-made changes may explain why the Wadden Sea ecosystem readily accommodated alien species without a concomitant loss of natives.

The course of previous alien species invasions into the Wadden Sea may not justify treating aliens as an urgent threat to native biodiversity. On the other hand, we observe an increasing number of species that also occur at other coastal regions. This advancing globalization entails a fading degree of biological uniqueness, and such a process is in conflict with the aim of nature conservation to sustain natural conditions. Management cannot reverse history but could implement measures which mitigate this development, i.e., by further reducing eutrophication, covering hard shores with sand and trying to minimize introducing alien substrates.

A problem for management arises from the limited predictability whether an alien will be harmless or turn into a threat before it has attained a wide spread and high abundance in a recipient region, and then it is - except for islands and lakes - not feasible anymore to reverse the invasion, particularly in the case of aquatic invertebrates and plants as in the Wadden Sea. Species differ in invasibility. However, a species-by-species approach cannot cope with cumulative effects and in protected nature areas as in the Wadden Sea (see the trilateral Wadden Sea Plan (CWSS, 2010)) alien introductions are generally not wanted. This justifies a generic attitude of preventing, eradicating or controlling nonnative species.

The Wadden Sea ecosystem is pervaded by wide-spread and abundant alien species such as the hybrid grass S. anglica forming a coherent belt at the outer edge of salt marshes, the Pacific oyster $C$. gigas replacing former mussel beds or the high biomass of the American razor clam Ensis (directus) americanus in the subtidal zone where native clams are scarce (Nehring et al., 2009). Many abundant aliens in the Wadden Sea belong to the functional group of suspension feeders, i.e., C. gigas, the American slipper limpet Crepidula fornicata, E. americanus (Reise and van Beusekom, 2008; Tulp et al., 2010). Presumably, the reinforced guild of benthic suspension feeders has increased its pressure on small pelagic organisms such as phytoplankton and larvae of benthic invertebrates. In addition, more fecal material and shells accumulate in the sediment. Together, it constitutes an ongoing change in the functioning of the Wadden Sea ecosystem, and this development is in conflict with the aim of protecting natural processes, and justifies management to stop the flood of new invaders.

The interactions of aliens with natives and among each other reveal an extraordinary complexity of competitive, predator-prey as well as parasite-host relationships with inhibiting and facilitating effects (Reise et al., 2006). For example, the slipper limpet C. fornicata affects mussels to which it is attached negatively but 


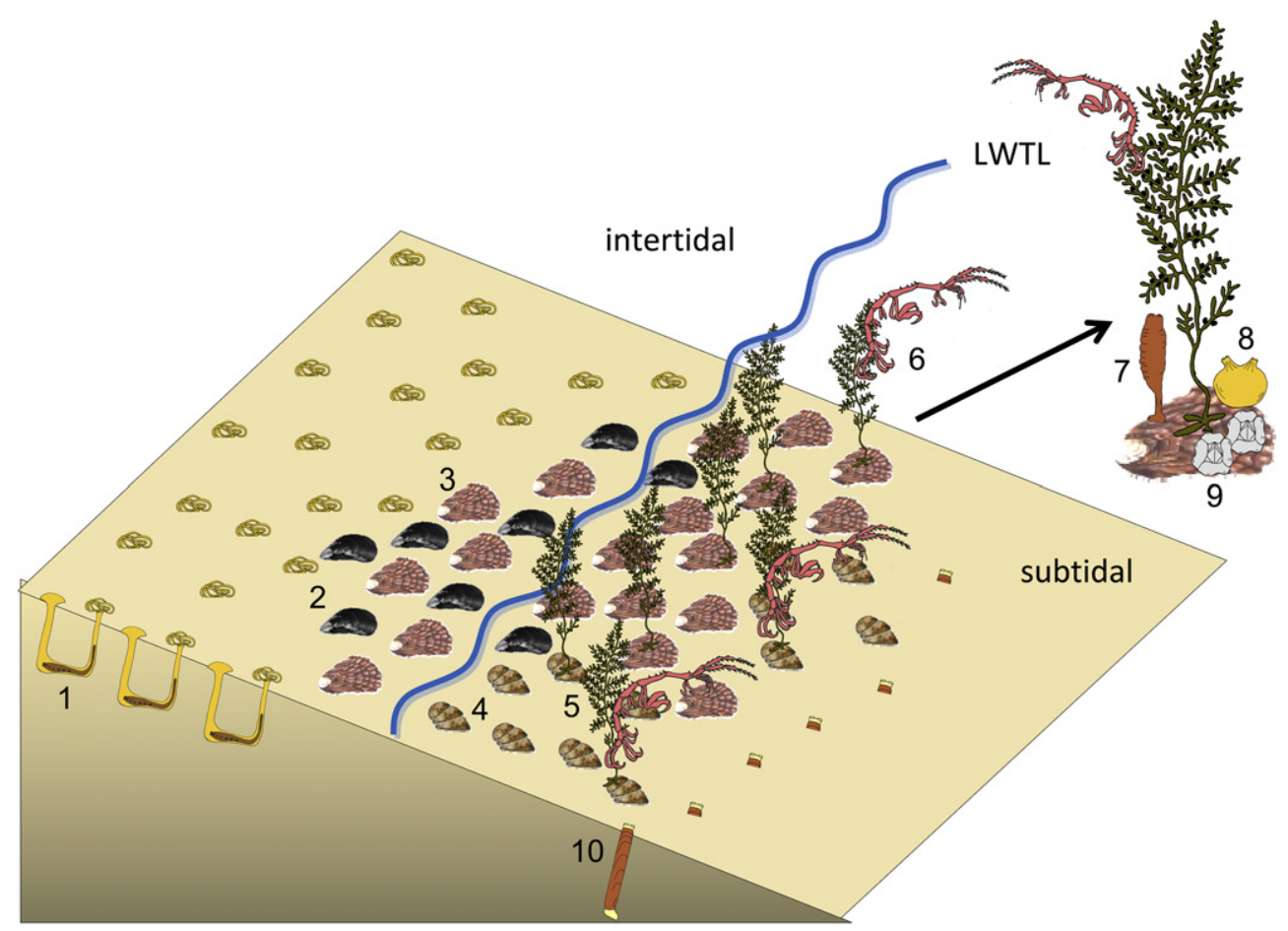

Fig. 2. Prominent species occurring from the mid intertidal to the subtidal zone in the northern Wadden Sea. Intertidally, native species such as the lugworm Arenicola marina (1) and mussels Mytilus edulis (2) are abundant while the shallow subtidal zone is characterized by alien habitat engineers such as Crassostrea gigas (3), Crepidula fornicata (4), Sargassum muticum (5) which provide habitat for many mobile and fouling nonnatives including Caprella mutica (6), the tunicates Styela clava (7), Molgula manhattensis (8) and the barnacle Austrominius modestus (9). The American razor clam Ensis americanus (10) is the dominant bivalve in the subtidal zone. LWTL: Low Water Tide Line. Modified after Buschbaum and Reise, 2010.

also protects them against predators and parasite infections (Thieltges et al., 2006, 2009). Within oyster reefs, the native mussels are relegated to dwell in niches between the much larger oysters which results in decreased growth but increased survival due to refuges from crabs and other predators (Eschweiler and Christensen, 2011). The razor clam Ensis americanus has become one of the most abundant shellfish and also an important prey for fish and birds (Freudendahl et al., 2010; Tulp et al., 2010) but the effect on its planktonic food is still unknown and has not been studied yet. Alien plants and large benthic invertebrates function as ecosystem engineers, creating new habitat structures (Wallentinus and Nyberg, 2007; Bouma et al., 2009; Tang and Kristensen, 2010). This may facilitate native and alien species alike in a habitat otherwise poor in epibenthos (Fig. 2; Buschbaum et al., 2006; Polte and Buschbaum, 2008) but may also turn out to inhibit some species (Lang and Buschbaum, 2010).

Alien species in the Wadden Sea have not only increased regional species richness and ecological complexity but also evolutionary change is inevitably entailed in mixed nativenonnative species assemblages. Such eco-evolutionary dynamics between non natives and the recipient system have indelible results which cannot be simply reversed (Carroll, 2011). Invading populations will tend to differ more and more from their source populations and co-evolution will ultimately soften the distinction between nonnatives and natives in the invaded region. This is an argument to refrain from eradicating already established alien species.

There are several unanswered questions. Is the clam Mya arenaria still to be regarded as an alien although present in the Wadden Sea since several centuries? Does this old alien species deserve more rights to remain than the more recently introduced razor clam E. americanus? Both have attained an essential role in the food web and it would be impossible to remove them without strong effects and presumable damage to the entire ecosystem. Clearly this is neither desirable nor feasible. When the native barnacle Semibalanus balanoides begins to decline in the wake of climatic warming, would it then be better to have an empty niche on intertidal hard substrates or to have this niche filled by the Australian barnacle Austrominius modestus, which has been introduced several decades ago and now benefits from milder winters and warmer summers (see Witte et al., 2010)?

We suggest that in the open coastal ecosystem of the protected Wadden Sea, the already established alien species deserve the same treatment as do the native species. Without such a decision, environmental management would embark on an endless chain of manipulating species compositions and species interactions, which would be in conflict with the aim to let natural processes proceed as far as possible in this protected nature area. On the other hand, mitigating the ongoing flood of alien invasions by controlling the vectors and attempting eradications before a firm establishment has occurred (Williams and Grosholz, 2008) should deserve priority in the nature management of the Wadden Sea and beyond.

\section{Conclusions}

(1) With a total of 49 nonnative and 17 cryptogenic species of marine-to-brackish macrobenthic organisms established in the Wadden Sea, this shallow sedimentary coast has received an average amount of aliens compared to inventories of other coastal regions.

(2) The prevalence of secondary introductions in the Wadden Sea necessitates that regular assessments of alien species with a focus on harbors, marinas and shellfish farms should be 
performed in concert with similar surveys all along the European Atlantic coast.

(3) Artificial hard structures play a key role in the establishment and spread of introduced alien species and should be minimized in the sedimentary Wadden Sea.

(4) The Wadden Sea ecosystem is heavily pervaded by nonnative species. However, the resulting eco-evolutionary development is irreversible and the already established alien species should be tolerated and not treated differently from native species.

(5) For mitigating the ongoing flood of alien invasions, concerted management over the entire Atlantic coast of Europe should focus on vector control and eradication prior to firm establishment at gateway sites of alien introductions rather than on the scale of the Wadden Sea alone.

\section{Acknowledgments}

We thank Rolf Karez and the State Agency for Agriculture, Environment and Rural Areas, Flintbek (LLUR-SH) for supervising and funding our projects on alien species in German coastal waters, and also Jan Witt (Lower Saxony Water Management, Coastal Defence and Nature Conservation Agency, NLWKN) for project support. Advice from Wolfgang Groepler and Ralph Kuhlenkamp on taxonomic questions has been extremely helpful. We thank three anonymous reviewers for identifying omissions, for constructive criticism and their encouragement.

\section{References}

Arenas, F., Bishop, J.D.D., Carlton, J.T., Dyrynda, P.J., Farnham, W.F., Gonzalez, D.J., Jacobs, M.W., Lambert, C., Lambert, G., Nielsen, S.E., Pederson, J.A., Porter, J.S., Ward, S., Wood, C.A., 2006. Alien species and other notable records from a rapid assessment survey of marinas on the south coast of England. J. Mar. Biol. Assoc. U.K. 86, 1329-1337.

Armonies, W., Reise, K., 2003. Empty habitat in coastal sediments for populations of macrozoobenthos. Helgol. Mar. Res. 56, 279-287.

Ashton, G., Boos, K., Shucksmith, R., Cook, E., 2006. Rapid assessment of the distribution of marine non-native species in marinas in Scotland. Aquat. Invasions 1 (4), 209-213.

Bastrop, R., Blank, M., 2006. Multiple invasions - a polychaete genus enters the Baltic Sea. Biol. Invasions 8, 1195-1200.

Ben-Shlomo, R., Paz, G., Rinkevich, B., 2006. Postglacial-period and recent invasions shape the population genetics of botryllid ascidians along European Atlantic coasts. Ecosystems 9, 1118-1127.

Bouma, T.J., Olenin, S., Reise, K., Ysebaert, T., 2009. Ecosystem engineering and biodiversity in coastal sediments: posing hypotheses. Helgol. Mar. Res. 63, 95-106.

Briggs, J.C., 2010. Marine biology: the role of accommodation in shaping marine biodiversity. Mar. Biol. 157, 2117-2126.

Buschbaum, C., Gutow, L., 2005. Mass occurrence of an introduced crustacean (Caprella cf. mutica) in the south-eastern North Sea. Helgol. Mar. Res. 59, $252-253$.

Buschbaum, C., Reise, K., 2010. Neues Leben im Weltnaturerbe Wattenmeer. Globalisierung unter Wasser. Biol. Unserer Zeit 40 (3), 202-210.

Buschbaum, C., Chapman, A.S., Saier, B., 2006. How an introduced seaweed can affect epibiota diversity in different coastal systems. Mar. Biol. 148, 743-754.

Buschbaum, C., Mayr, T., Scheuer, K., 2008. Vorkommen der invasiven Rotalge Gracilaria vermiculophylla und ihre ökologischen Effekte im SchleswigHolsteinischen Wattenmeer. Landesamt für Natur und Umwelt des Landes Schleswig-Holstein, Flintbek, pp. 1-50.

Campbell, M.L., Gould, B., Hewitt, C.L., 2007. Survey evaluations to assess marine bioinvasions. Mar. Poll. Bull. 55, 360-378.

Carlton, J.T., 1989. Man's role in changing the face of the ocean: biological invasions and implications for conservation of near-shore environments. Conserv. Biol. 3, 265-273.

Carlton, J.T., 1996. Biological invasions and cryptogenic species. Ecology 77, $1653-1655$.

Carroll, S.P., 2011. Conciliation biology: the eco-evolutionary management of permanently invaded biotic systems. Evol. Appl. 4, 184-199.

Cohen, A.N., Carlton, J.T., 1995. Nonindigenuous Aquatic Species in a United Sates Estuary: A Case Study of the Biological Invasions of the San Francisco Bay and Delta. U.S. Fish and Wildlife Service, Arlington, Virginia, USA.

Cohen, A.N., Harris, L.H., Bingham, B.L., Carlton, J.T., Chapman, J.W., Lambert, C.C., Lambert, G., Ljubenkov, J.C., Murray, S.N., Rao, L.C., Reardon, K., Schwindt, E., 2005. Rapid assessment survey for exotic organisms in southern California bays and harbors, and abundance in port and non-port areas. Biol. Invasions 7, 995-1002.
Craig, M.T., 2010. Pattern versus process: broadening the view of marine invasive species. Mar. Biol. 157, 2127-2128.

CWSS, 2008. Nomination of the Dutch-GermanWadden Sea as World Heritage Site. WaddenSea Ecosystem No. 24. CommonWadden Sea Secretariat, Wilhelmshaven, Germany, pp. 1-200.

CWSS, 2010. Wadden Sea Plan 2010. CommonWadden Sea Secretariat, Wilhelmshaven, Germany. www.waddensea-secretariat.org, pp. 1-88.

Davis, M., et al., 2011. Don't judge species on their origins. Nature 474, 153-154 (see also correspondence in Nature 475, 36-37 and Science 333, 404-405).

Den Hartog, C., 1963. The amphipods of the Deltaic region of the rivers Rhine, Meuse and Scheldt in relation to the hydrography of the area. Neth. J. Sea Res. 2, 40-67.

Dittmer, J.D., 1981. The distribution of subtidal macrobenthos in the estuaries of the rivers Ems and Weser. In: Dankers, N., Kühl, H., Wolff, W. (Eds.), Invertebrates of the Wadden Sea, Report 4. Balkema, Rotterdam, pp. 188-206.

Dürr, A., 2010. Untersuchungen zur Populations- und Fortpflanzungsbiologie von Garnelen in der westlichen Ostsee. Diplom-thesis. Univ. Kiel, p. 160.

Elsner, N.O., Jacobsen, S., Thieltges, D.W., Reise, K., 2011. Alien parasitic copepods in mussels and oysters of the WaddenSea. Helgol. Mar. Res. 65, 299-307.

Eno, N.C., Clark, R.A., Sanderson, W.G., 1997. Non-native Marine Species in British Waters: A Review and Directory. Joint Nature and Conservation Committee, Peterborough, p. 152

Eschweiler, N., Christensen, H.T., 2011. Trade-off between increased survival and reduced growth for blue mussels living on Pacific oyster reefs. J. Exp. Mar. Biol. Ecol. 403, 90-95.

Essink, K., Kleef, H.L., 1993. Distribution and life cycle of the North American spionid Marenzelleria viridis (Verrill, 1873) in the Ems estuary. Neth. J. Aquatic Ecol. 27, 237-246.

Faasse, M., Ligthart, M., 2009. American (Urosalpinx cinerea) and Japanese oyster drill (Ocinebrellus inornatus) (Gastropoda: Muricidae) flourish near shellfish culture plots in The Netherlands. Aqua. Invasions 4, 321-326.

Freudendahl, A.S.L., Nielsen, M.M., Jensen, T., Jensen, K.T., 2010. The introduced clam Ensis americanus in the Wadden Sea: field experiment on impact of bird predation and tidal level on survival and growth. Helgol. Mar. Res. 64, 93-100.

Fritts, T.H., Rodda, G.H., 1998. The role of introduced species in the degradation of island ecosystems: a case history of Guam. Annu. Rev. Ecol. Syst. 29, 113-140.

Frost, J.R., Jacoby, C.A., Youngbluth, M.J., 2010. Behavior of Nemopsis bachei L. Agassiz, 1849 medusae in the presence of physical gradients and biological thin layers. Hydrobiologia 645, 97-111.

Galil, B.B., 2009. Taking stock: inventory of alien species in the Mediterranean Sea. Biol. Invasions 11, 359-372.

Gittenberger, A., Rensing, M., Stegenga, H., Hoeksema, B., 2010. Native and nonnative species of hard substrata in the Dutch Wadden Sea. Nederlandse Faunistische Medelingen 33, 21-75.

Gollasch, S., Nehring, S., 2006. National checklist for aquatic alien species in Germany. Aqua. Invasions 1 (4), 245-269.

Gollasch, S., Haydar, D., Minchin, D., Wolff, W.J., Reise, K., 2009. Introduced aquatic species of the North Sea coasts and adjacent brackish waters. In: Rilov, G., Crooks, J.A. (Eds.), Biological Invasions in Marine Ecosystems. Ecol. Stud, vol. 204, pp. 507-528.

Gollasch, S., 2006. NOBANIS - Invasive Alien Species Fact Sheet - Eriocheir sinensis. From: Online Database of the North European and Baltic Network on Invasive Alien Species - NOBANIS. www.nobanis.org 2011.

González-Ortegón, E., Cuesta, J.A., Schubart, C.D., 2007. First report of the oriental shrimp Palaemon macrodactylus Rathbun, 1902 (Decapoda, Caridea, Palaemonidae) from German waters. Helgol. Mar. Res. 61, 67-69.

Gurevitch, J., Padilla, D.K., 2004. Are invasive species a major cause of extinctions? Trends Ecol. Evol. 19 (9), 470-474.

Haydar, D., Hoarau, G., Olsen, J.L., Stam, W.T., Wolff, W., 2011. Introduced or glacial relict: phylogeography of the cryptogenic tunicate Molgula manhattensis (Ascidiacea, Pleurogona). Divers. Distrib 17, 68-80.

Hewitt, C.L., Campbell, M.L., Thresher, R.E., et al., 2004. Introduced and cryptogenic species in Port Phillip Bay, Victoria, Australia. Mar. Biol. 144, 183-202.

Jensen, K.R., Knudsen, J., 2005. A summary of alien marine benthic invertebrates in Danish waters. Oceanol. Hydrobiol. Stud. 24 (1), 137-162.

Jensen, K.T., 1992. Macrozoobenthos on an intertidal mudflat in the Danish Wadden Sea: comparisons of surveys made in the 1930s, 1940s and the 1980s. Helgoländer Meeresunters 46, 363-376.

Klein, G., 1969. Amphipoden aus der Wesermündung und der Helgoländer Bucht, mit Beschreibung von Talorchestia frisiae n. sp. Veröff. Inst. Meeresforsch. Bremerhaven 11, 173-194.

Koops, H., Hartmann, F., 1989. Anguillicola-infestations in Germany and in German eel imports. J. Appl. Ichthyol. 1, 41-45.

Kremer, B.P., Kuhbier, H., Michaelis, H., 1983. Die Ausbreitung des Brauntanges Sargassum muticum in der Nordsee. Natur und Museum 113, 125-130.

Lambertini, M., et al., 2011. Invasives: a major conservation threat. Science 333 , 404-405.

Lang, A.C., Buschbaum, C., 2010. Facilitative effects of introduced Pacific oysters on native macroalgae are limited by a secondary invader, the seaweed Sargassum muticum. J. Sea Res. 63, 119-128.

Leppäkoski, E., Gollasch, S., Olenin, S. (Eds.), 2002. Invasive Aquatic Species of Europe. Distribution, Impacts and Management. Kluwer Academic Publishers, Dordrecht, p. 583. 
Lockwood, J.L., 2004. How do biological invasions alter diversity patterns? A biogeographic perspective. In: Lomolino, M.V., Heaney, L.R. (Eds.), Frontiers of Biogeography. Sinauer Assocaites, Sunderland, MA, pp. 271-310.

Loebl, M., Van Beusekom, J.E.E., Reise, K., 2006. Is spread of the neophyte Spartina anglica recently enhanced by increasing temperatures? Aqua. Ecol. 40, 315-324.

Lotze, H.K., et al., 2005. Human transformations of the Wadden Sea ecosystem through time: a synthesis. Helgol. Mar. Res. 59, 84-95.

Lövei, G.L., 1997. Global change through invasion. Nature 388, 627.

Lützen, J., 1999. Styela clava (Urochordata, Ascidiacea), a successful immigrant to North West Europe: ecology, propagation and chronology of spread. Helgoländer Meeresunters 52, 383-391.

Marencic, H. (Ed.), 2009. The Wadden Sea - Introduction. Thematic Report No. 1. In Marencic, H. \& 1de Vlas, J. (Eds), 2009. Quality Status Report 2009. Wadden Sea Ecosystem No. 25. Common Wadden Sea Secretariat, Trilateral Monitoring and Assessment Group, Wilhelmshaven, Germany, pp. 3-24.

McKinney, M.L., Lockwood, J.L., 1999. Biotic homogenization: a few winners replacing many losers in the next mass extinction. Trends Ecol. Evol. 14 (11), 450-452.

Minchin, D., 2007a. Rapid coastal survey for targeted alien species associated with floating pontoons in Ireland. Aqua. Invasions 2 (1), 63-70.

Minchin, D., 2007b. A checklist of alien and cryptogenic aquatic species in Ireland. Aqua. Invasions 2, 341-366.

Nehls, G., Büttger, H., 2007. Spread of the Pacific Oyster Crassostrea gigas in the Wadden Sea - Causes and Consequences of a successful invasion. Trilatera Workshop on Pacific Oyster Invasion in the Wadden Sea, vol. 22. Common Wadden Sea Secretariat, Wilhelmshaven, Germany, p. 54.

Nehls, G., Diederich, S., Thieltges, D.W., Strasser, M., 2006. Wadden Sea mussel beds invaded by oysters and slipper limpets: competition or climate control? Helgol. Mar. Res. 60, 135-143.

Nehring, S., Hesse, K.-J., 2008. Invasive alien plants in marine protected areas: the Spartina anglica affair in the European Wadden Sea. Biol. Invasions 10, 937-950.

Nehring, S., Leuchs, H., 1999. Neozoa (Makrobenthos) an der deutschen Nordseeküste. Eine Übersicht. Bundesanstalt für Gewässerkunde, Koblenz, p. 131.

Nehring, S., Reise, K., Dankers, N., Kristensen, P.S., 2009. Alien species. Thematic report No. 7. In: Marencic, H., de, Vlas J. (Eds.), Quality Status Report 2009. Wadden Sea Ecosystem No. 25. CommonWadden Sea Secretariat, Trilateral Monitoring and Assessment Group, Wilhelmshaven, Germany.

Nehring, S., 2000. Zur Bestandssituation von Rhithropanopeus harrisii (GOULD, 1841) in deutschen Gewässern: Die sukzessive Ausbreitung eines amerikanischen Neozoons. Senckenbergiana maritima 30,115-122.

Nielsen, R., 2005. Danish Seaweeds. Botanical Museum Copenhagen, Denmark.

Obert, B., Herlyn, M., Grotjahn, M., 2007. First records of two crabs from the North West Pacific Hemigrapsus sanguineus and $H$. takanoi at the coast of Lower Saxony. Germany Wadden Sea Newsl., 21-22. 2007-1.

Occhipinti-Ambrogi, A., Galil, B., 2010. Marine alien species as an aspect of globa change. Adv. Oceanogr. Limnol. 1 (1), 143-156.

Occhipinti-Ambrogi, A., et al., 2011. Alien species along the Italian coasts: an overview. Biol. Invasions 13, 215-237.

Olden, J.D., LeRoy Poff, N., Douglas, M.R., Douglas, M.E., Fausch, K.D., 2004 Ecological and evolutionary consequences of biotic homogenization. Trends Ecol. Evol. 19 (1), 18-24.

Osterkamp, S., Schirmer, M., 2000. Projekt 'Klimaänderung und Unterweserregion' (Fallstudie Weserästuar), Bund-Länder-Programm 'Klimaänderung und Küste' Universität Bremen, p. 151.

Paavola, M., Olenin, S., Leppäkoski, E., 2005. Are invasive species most successful in habitats of low native species richness across European brackish water seas? Est. Coast. Shelf Sci. 64, 738-750.

Polte, P., Buschbaum, C., 2008. Native pipefish Entelurus aequoreus are promoted by the introduced seaweed Sargassum muticum in the northern Wadden Sea. Aquat. Biol. 3, 11-18.

Post, D., Landmann, M., 1994. Verbreitungsatlas der Fließgewässerfauna in Ostfriesland. Staatliches Amt für Wasser und Abfall, Aurich, p. 141.

Reise, K., Buschbaum, C., 2007. Mehr Sand statt Stein für die Ufer der Nordseeküste. Rostocker Meeresbiologische Beiträge 17, 77-86.

Reise, K., Lackschewitz, D., 2003. Combating habitat loss at eroding Wadden Sea shores by sand replenishments. In: Wolff, W.J., Essink, K., Kellermann, A. van Leeuwe, M.A. (Eds.), Challenges to the Wadden Sea. Proceedings of the 10th Int. Sci. Wadden Sea Symp. Groningen 2000. Ministry of Agriculture, Nature Management and Fisheries, Dept. Mar. Biol. Univ. Groningen, pp. 197-206.

Reise, K., van Beusekom, J.E.E., 2008. Interactive effects of global and regional change on a coastal ecosystem. Helgol. Mar. Res. 62, 85-91.

Reise, K., Herre, E., Sturm, M., 1994. Biomass and abundance of macrofauna in intertidal sediments of Königshafen in the northern Wadden Sea. Helgoländer Meeresunters 48, 201-215.

Reise, K., Gollasch, S., Wolff, W.J., 1999. Introduced marine species of the North Sea coasts. Helgoländer Meeresunters 52, 219-234.

Reise, K., Dankers, N., Essink, K., 2005. Introduced species. In: Essink, K. Dettmann, C., Farke, H., Laursen, K., Lüerßen, G., Marencic, H., Wiersinga, W. (Eds.), Wadden Sea Quality Status Report 2004. Wadden Sea Ecosystem No. 19. Common Wadden Sea Secretariat, Wilhelmshaven, Germany, pp. 155-161.

Reise, K., Olenin, S., Thieltges, D.W., 2006. Are aliens threatening European aquatic coastal ecosystems? Hegol. Mar. Res. 60, 77-83.
Reise, K., Baptist, M., Burbridge, P., Dankers, N., Fischer, L., Flemming, B., Oost, A.P., Smit, C., 2010. The Wadden Sea - a universally outstanding tidal wetland. Wadden Sea Ecosys. 29, 9-23. Common Wadden Sea Secretariat, Wilhelmshaven, Germany.

Reise, K., 1990. Historische Veränderungen in der Ökologie des Wattenmeeres. Rhein.-Westfäl. Akad. Wiss., Vorträge N 382, 35-50.

Reise, K., 1998. Pacific oysters invade mussel beds in the European Wadden Sea. Senckenbergiana marit. 28 (4/6), 167-175.

Ruesink, J.L., Lenihan, H.S., Trimble, A.C., Heiman, K.W., Micheli, F., Byers, J.E. Kay, M.C., 2005. Introduction of non-native oysters: ecosystem effects and restoration implications. Annu. Rev. Ecol. Evol. Syst. 36, 643-689.

Ruijter, R. de, 2008. Cs-verslag. Het Zeepaard 68 (5), 2-7.

Ruiz, G.M., Carlton, J.T., Grosholz, E.D., Hines, A.H., 1997. Global invasions of marine and estuarine habitats by non-indigenous species: mechanisms, extent and consequences. Am. Zool. 37, 621-632.

Ruiz, G.M., Fofonoff, P., Hines, A.H., Grosholz, E.D., 1999. Non-indigenous species as stressors in estuarine and marine communities: assessing invasion impacts and interactions. Limnol. Oceanogr. 44 (3), 950-972.

Ruiz, G.M., Fofonoff, P., Carlton, J.T., Wonham, M.J., Hines, A.H., 2000. Invasion of coastal marine communities in North America: apparent patterns, processes and biases. Annu. Rev. Ecol. Syst. 31, 481-531.

Rüppell, G., 1967. Zur Lokomotionsaktivität des Amphipoden Orchestia platensis im Freiland und im Laboratorium. Helgoländer Meeresunters 15, 172-180.

Ryland, J.S., Bishop, J.D.D., Blauwe, H. De, Nagar, A. El, Minchin, D., Wood, C.A., Yunnie, A.L.E., 2011. Alien species of Bugula (Bryozoa) along the Atlantic coasts of Europe. Aqua. Invasions 6, 17-31.

Schories, D., Albrecht, A., 1995. Sargassum muticum - Der japanische Beerentang im deutschen Wattenmeer. Natur und Museum 125, 92-98.

Schories, D., Albrecht, A., Lotze, H., 1997. Historical changes and inventory of macroalgae from Königshafen Bay in the Northern Wadden Sea. Helgoländer Meeresunters 51, 321-341.

Simberloff, D., 2009. We can eliminate invasions or live with them. Successful management projects. Biol. Invasions 11, 149-157.

Smidt, E.L.B., 1951. Animal production in the Danish Waddensea. Meddelelser fra Kommissionen for Danmarks Fiskeri- og Havundersögelser Serie: Fiskeri XI (6)

Soest, R.W.M. van, Kluijver, M.J. de, Bragt, P.H. van, Faasse, M., Nijland, R., Beglinger, E., Weerdt, W.H. de, Voogd, N.J. de, 2007. Sponge invaders in Dutch coastal waters. J. Mar. Biol. Ass. U.K 87, 1733-1748.

Strasser, M., Walensky, M., Reise, K., 1999. Juvenile-adult distribution of the bivalve Mya arenaria on intertidal flats in the Wadden Sea: why are there so few year classes? Helgol. Mar. Res. 53, 45-55.

Streftaris, N., Zenetos, A., Papathanassiou, E., 2005. Globalisation in marine ecosystems: the story of non-indigenous marine species across European seas. Oceanogr. Mar. Biol. Ann. Rev. 43, 419-454.

Swennen, C., Dekker, R., 1995. Corambe batava Kerbert, 1886 (Gastrpoda, Opisthobranchia), an immigrant in The Netherlands, with a revision of the family Corambidae. J. Molluscan Stud. 61, 97-107.

Tang, M., Kristensen, E., 2010. Associations between macrobenthos and invasive cordgrass, Spartina anglica, in the Danish Wadden Sea. Helgol. Mar. Res. 64 321-329.

Thieltges, D.W., Strasser, M., Reise, K., 2006. How bad are invaders in coastal waters? The case of the American slipper limpet Crepidula fornicata in western Europe. Biol. Invasions 8, 1673-1680.

Thieltges, D.W., Reise, K., Prinz, K., Jensen, K.T., 2009. Invaders interfere with native parasite-host interactions. Biol. Invasions 11, 1421-1429.

Thomsen, M.S., Staehr, P.A., Nyberg, C., Schwaerter, S., Krause-Jensen, D. Silliman, B.R., 2007a. Gracilaria vermiculophylla (Ohmi) Papenfuss, 1967 (Rhodophyta, Gracilariaceae) in northern Europe, with emphasis on Danish conditions, and what to expect in the future. Aqua. Invasions 2, 83-94.

Thomsen, M.S., Wernberg, T., Staehr, P.A., Krause-Jensen, D., Risgaard-Petersen, N., Silliman, B.R., 2007b. Alien macroalgae in Denmark - a broad-scale national perspective. Marine Biol. Res. 3, 61-72.

Tulp, I., Craeymeersch, J., Leopold, M., van Damme, C., Fey, F., Verdaat, H., 2010. The role of the invasive bivalve Ensis directus as food source for fish and birds in the Dutch coastal zone. Est. Coast. Shelf Sci. 90, 116-128.

Vervoort, W., 1964. Note on the distribution of Garveia franciscana (Torrey, 1902) and Cordylophora caspia (Palls, 1771) in the Netherlands. Zool. Meded 39. $125-146$.

Graaf, S., van der Vlas, J., de, Herlyn, M. Voss, J., Heyer, K., Drent, J., 2009. Macrozoobenthos. Thematic report no. 10. In: Marencic, H., Vlas, J. de(Eds.), Quality Status Report 2009. Wadden Sea Ecosystem No. 25. Common Wadden Sea Secretariat Trilateral Monitoring and Assessment Group Wilhelmshaven, Germany.

Wallentinus, I., Nyberg, C.D., 2007. Introduced marine organisms as habitat modifiers. Mar. Pollut. Bull. 55, 323-332.

Wang, C., Li, S., Fu, C., Gong, X., Huang, L., Song, X., Zhao, Y., 2009. Molecular genetic structure and evolution in native and colonized populations of the Chinese mitten crab, Eriocheir sinensis. Biol. Invasions 11, 389-399.

Wasson, K., Zabin, C.J., Bedinger, L., Diaz, M.C. Pearse, J.S., 2001. Biological invasion of estuaries without international shipping: the importance of intraregional transport. Biol. Conservation 102, 143-153.

Westheide, W., 1966. Zur Polychaetenfauna des Eulitorals der Nordseeinsel Sylt Helgoländer wiss. Meeresunters 13, 2003-2009.

Williams, S.L., Grosholz, E.D., 2008. The invasive species challenge in estuarine and coastal environments: marrying management and science. Estuaries and Coasts $31,3-20$. 
Witt, J., Krumwiede, A., 2006. Fahrrinnenanpassung der Unterweser an die Entwicklungen im Schiffsverkehr. Entwicklung eines Bewertungskonzeptes und Bewertung des Makrobenthos der Unterweser. Im Auftrag des Wasser- und Schiffahrtsamtes Bremerhaven (WSA).

Witte, S., Buschbaum, C., Beusekom, J.E.E. van, Reise, K., 2010. Does climatic warming explain why an introduced barnacle finally takes over after a lag of more than 50 years? Biol. Invasions 12, 3579-3589.

Wolff, W.J., Dankers, N., 1981. Preliminary checklist of the zoobenthos and nekton species of the Wadden Sea. In: Dankers, N., Kühl, H., Wolff, W. (Eds.), Invertebrates of the WaddenSea, Report 4. Balkema, Rotterdam, pp. 24-60.

Wolff, W.J., Bakker, J.P., Laursen, K., Reise, K. 2010. The Wadden Sea Quality Status Report - Synthesis Report 2010. Wadden Sea Ecosystem No. 29. Common Wadden Sea Secretariat, Wilhelmshaven, Germany, pp 27-71.
Wolff, W.J., 1999. Exotic invaders of the meso-oligohaline zone of estuaries in The Netherlands: why are there so many? Helgol. Meeresunters 52, 393-400.

Wolff, W.J., 2000a. Causes of extirpations in the Wadden Sea, an estuarine area in The Netherlands. Conserv. Biol. 14, 876-885.

Wolff, W.J., 2000b. The south-east North Sea: losses of vertebrate fauna during the past 2000 years. Biol. Cons. 95, 209-217.

Wolff, W.J., 2005. Non-indigenous marine and estuarine species in the Netherlands. Zoologische Mededelingen 79 (1), 1-116.

Wonham, M.J., Carlton, J.T., 2005. Trends in marine biological invasions at local and regional scales: the Northeast Pacific Ocean as a model system. Biol. Invasions 7 , 369-392.

Wrange, A.-L., Valero, J., Harkestad, LS., Strand Ø Lindegarth, S., Christensen, H.T., Dolmer, P., Kristensen, P.S., Mortensen, S., 2010. Massive settlements of Pacific oyster, Crassostrea gigas, in Scandinavia. Biol. Invasions 12, 1453-1458. 